\title{
The impact of the spatial configuration of socioeconomic services on rural-urban dependencies in Northern Jordan
}

\author{
Anne A. Gharaibeh (D) Mohammad N. Alhamad - Doraed A. Al-Hassan • \\ Naser I. Abumustafa
}

Accepted: 23 August 2021/Published online: 15 September 2021

(C) The Author(s), under exclusive licence to Springer Nature B.V. 2021

\begin{abstract}
This study investigates the actual use of services and accessibility of employment places by rural residents while interacting with their surrounding towns, urban center, and the county rural center. This study reveals the factors contributing to rural-urban dependence in a developing country in terms of services and job utilization. Its pursuit is developing policies for regional sustainability. Therefore, a rural survey was carried out to identify the actual dependence. The study found that rural residents were integrated significantly with the urban center regarding shopping, education, and medical services rather than jobs, with minor interdependencies among rural towns. The continued and mass dependence on the
\end{abstract}

A. A. Gharaibeh $(\square) \cdot$ D. A. Al-Hassan $(\square)$

Department of City Planning and Design, College of Architecture and Design, Jordan University of Science and Technology, P.O. Box 3030, Irbid 22110, Jordan e-mail:dr-anne@just.edu.jo

D. A. Al-Hassan

e-mail: doraed.alhassan@student.hswt.de

M. N. Alhamad

Department of Natural Resources and Environment, Jordan University of Science and Technology,

P.O. Box 3030, Irbid 22110, Jordan

e-mail: malhamad@just.edu.jo

N. I. Abumustafa

Qatar Finance and Business Academy (QFBA),

Northumbria University, Doha, Qatar

e-mail: drnaser69@hotmail.com urban center was depleting rural resources creating a rural-urban gap in economic development. The study recommended a development strategy that emphasizes the importance of preserving rural living and jobs. It emphasized the importance of the urban center in providing jobs for the rural people rather than long journeys to obtain services.

Keywords Rural-Urban gaps · Regional planning · Economic planning $\cdot$ Rural-urban dependence $\cdot$ Rural development · Urban planning

\section{Introduction}

The development of rural areas aims at improving the livelihood of rural people; both environmentally and socially. This is accomplished by improving access to physical, natural, human, social, capital, and technical assets. It is also managed by providing services that improve the livelihoods of rural communities equitably and sustainably (Anlimachie \& Avoada, 2020; Giuliani, 2003; Partridge et al., 2008). According to the UN data, the global rural population is expected to decrease in both developed countries (from $21 \%$ in 2018 to $13 \%$ by 2050) and in less developed regions (from $49 \%$ in 2018 to almost $34 \%$ by 2050) (UN, 2018). To understand the rural/urban relationship and to reduce poverty, the global monitoring report 
(OECD, 2013) developed a rural-urban partnership approach as an economic development strategy.

There is much discussion now on sustainable and resilient futures. Some believe that producing food should become a concern in urban areas encouraging the urban and peri-urban agriculture notion (Langemeyer, et al., 2021; Woods, 2020). Others believe in "reruralization" and "deurbnaization" and strengthening the tie of the rural population to their place of settlement in rural areas (Woods, 2020). Staying at rural places and attending to agricultural fields and food production is currently considered one of the best scenarios for long-term sustainability. To sustain this, we must achieve equity for the rural population by providing them with the necessary services without jeopardizing their time or daily commutes (Meit \& Knudson, 2020; Zhao \& Yu, 2020).

Increasing attention is paid to the role of small urban towns in rural areas and the possibilities to improve the ties between these towns and their surrounding villages (Gashu, 2014; Sharifinia, 2013; Kassahun 2014). Rural development strategies aim to sustain and support the rural population to stay in their regions by enhancing them economically and improving their livability and quality of life (Partridge et al., 2010; Alinaghipour and Pourramzan, 2021). However, if a current rural place of residence doesn't provide the desired services, its population will be ready to move to urban places to access these services (Awasthi, 2021; Giuliani, 2003). Demand for services in rural areas necessitates daily movement, which is not equally accessible to all communities, hence widening the social inequality gap (Schönfelder et al., 2003; Zobena et al., 2012; Cattaneo et al., 2021).

Life patterns are rapidly shifting as a result of the dynamics of urban and rural expansion. This study calls into question the rural reliance on urban centers in a developing country with a rapidly rising population. Bani Kinanah County, located in northern Jordan, is a densely inhabited rural area. The rural population frequently travels to their urban center (the City of Irbid) to obtain daily essentials and gain access to services such as commodity shopping, healthcare, and education. The purpose of this research is to investigate the dynamics of Bani Kinanah County's ruralurban interdependence. It is investigating the real utilization of services by rural inhabitants as opposed to actual job locations. It is investigating the purpose of the citizens' everyday commutes.
In our world of ever-increasing urbanization, it is critical to strive to root inhabitants and reinforce their presence in their rural communities. This is anticipated to support farming as a career while also reducing the burden on our cities. The study explores how much of this rural community is reliant on their urban center for services, and how we can foster rural self-reliance regarding services.

\section{Literature review}

Rural residents tend to use services (medical, shopping, education, and everyday needs) in their town of residence, in nearby towns, in rural centers, and in urban centers. Some believe that improving the accessibility between rural towns is a more effective strategy than provisioning services in rural areas (Zobena et al., 2012). They found that the inefficiency of the public transportation system, failure to acquire a car, and low household income decrease mobility opportunities in rural areas and reduce the level of services supporting their existence in rural regions. Similarly, others emphasize the role of small rural towns as market towns for rural residents that have the potential for future resilience (Wales Assembly Governorate, 2007; Gashu, 2014; Kihonge, 2014; Zhou et al., 2021). In addition to the importance of service provision for the rural population, some recognize the importance of historical continuity of rural activities and their central role in preserving rural-urban relationships, preserving agricultural lands, and maintaining the sense of place (Gharaibeh et al., 2017, 2020; Karg et al., 2019; Wang et al., 2020).

Distance from service locations in sparsely populated areas is considered a strong barrier that reduces the accessibility to services (Garnelo et al., 2020). The inefficiency of the public transportation system, the lack of transport means, and socioeconomic status all play an important role in service accessibility in rural areas (Bryzhko \& Bryzhko, 2019; Zobena et al, 2012). The concept of the agglomeration of economic activities and the concept of demand threshold empower the urban areas to become the places for the majority of amenities and services (Castle et al., 2011). There are some examples where rural shopping in particular (wholesale, malls, tourist service, healthcare, etc.) is reducing reliance on urban centers and 
developing local multifunctional economies (Heffner \& Twardzik, 2015). This example also demonstrates how the appeal of such amenities will play a significant role in their success rate among rural residents.

In most instances, there is a disparity in service quality and availability between the urban and rural areas, forcing rural residents to rely on urban areas for services and quality shopping. Being keen on the equitable geographical distribution of economic activities, a study focusing on the impact of self-employment as a stimulating factor for rural development found a gap in the economic performance of rural regions (Faggio et al., 2014). It emphasized the necessity of enacting laws that encourage the transition of businesses from self-employment to entrepreneurship. If implemented, this improvement has the potential to boost the rural economy, rural employment, and rural service delivery (Faggio et al., 2014; Li et al., 2019).

Many studies examined the interaction between small urban towns and the surrounding rural areas and emphasized the role of small urban towns as areas of shopping for rural residents (Wales Assembly Governorate, 2007; Gashu, 2014; Kihonge, 2014; Mayer et al., 2016). Strengthening rural-urban accessibility is important for improving rural economies and decreasing rural economic gaps in their dependence on large cities (Lagakos, 2020; Rudiarto, et al., 2020). This strong interaccessibility or circulation between towns has a significant role in rural and regional development (Mayer et al., 2016; Tacoli, 2004; Vaughan, 2015).

Sharifinia (2013), reported the functional role of Mohammadabad town (a small urban center, Iran) in providing medical, educational, telecommunicational, administrative, and commercial services to its surrounding rural areas and in reducing the pressure on the city of Zabol (Sharifinia, 2013). Rezvani et al., (2009) found that the centralization of a variety of services in Roniz town decreases rural residents' dependence on Estahban city $(25 \mathrm{~km}$ away from Roniz town). Therefore, rural residents can access their services and facilities within a short distance and are not forced to travel long distances to the city of Estahban (Rezvani et al., 2009).

Partridge et al, (2008) examined the population dynamics in rural areas in small counties of the United States and reported that the linear influence of every kilometer further away from the larger urban area was associated with a $0.69 \%$ decrease in population growth. The study concluded that the impact of urban agglomeration in rural areas is limited by the long distance from the urban center. However, in some remote rural areas commuting to the urban areas is insufficient, thereby residents relocate closer to urban areas (Gharaibeh et al., 2021; Salvati, 2020). This is expected to create expanding cities and urban sprawl that jeopardize agricultural land (Gharaibeh et al., 2020).

learning from literature, the most visible form of rural-urban dependence is the commuting between rural places of residence to urban places of employment. Access to urban employment is the best strategy for rural development (Moss et al., 2004; Polese and Shearmur, 2006). Thus, access to urban agglomeration is the key source of population retention and growth for rural communities (Castle et al., 2011; Lavesson, 2017; Partridge et al., 2010). Needless to say that not only job opportunities are required to sustain rural existence, but also strategic planning to upgrade and develop rural towns in support of regional prosperity (Rudiarto et al., 2020).

In developing countries there is a lack of attention to the sources of rural and urban interaction and the data required to assess the factors of this interaction is not collected or not published based on sufficient details (Markova, 2019; United Nations, 2011). The practice of most developing strategies misses the point that the entire economic sector cannot be understood without receiving reliable knowledge concerning the urban and rural sectors and their interaction (Castle et al., 2011; Schaeffer et al., 2014).

In Jordan - which is a small, urbanized, lower to middle-income country - the actual numbers and the estimates of World Bank show that the rural population dropped from $49 \%$ in 1960 to $16 \%$ in 2015 to a mere $8.8 \%$ of the total population in 2019 (World Bank, 2018). In their statistical report published in 2018, the World Bank illustrated that the percentage of the citizens who work in farming is projected to drop from $8.59 \%$ in 1991 to $3.56 \%$ in 2019 (World Bank, 2018). Rural development approaches are coupled with the development of the agricultural sector and aimed to develop rural economies by examining the rural territory without taking into account the regional context of development.

The availability of services is one of the factors that drive Jordan's rural people to relocate to areas deemed to be inside urban agglomerations. In many instances, 
the rural population is foreseen to depend on the urban center for obtaining services (shopping, education, healthcare, entertainment, etc.) due to the unavailability of these services within the rural premises and due to the lowered quality and insufficiency of these services. This is translated in massive commutes of rural residents depending on private cars to obtain these services on daily basis. Although only $10 \%$ of the economy comes from farming by the rural population in Jordan (Adams, 2001), it is important to sustain living in rural areas to preserve land and agricultural practices and to secure food for the fastgrowing population. Jordan is facing many challenges including urban sprawl on agricultural land which is caused by the continuous rural-urban migration (Gharaibeh, 2020). A quick look at Google Earth maps in the past 10 years shows that many cities such as Amman, Irbid, Madaba, and Jerash are currently expanding towards the farming plains instead of the mountainous and rugged terranes.

This research concentrates on (i) realizing the spatial distribution of actual use of services (shopping, educational services, medical care, recreational services, and jobs) by rural residents, (ii) identifying the places that residents use to obtain each type of service and measures the proportion of the used services in each place (iii) focuses on revealing residents' interaction with their urban center and rural administrative center, and (iv) overall interaction and spatial distribution of service utilization within the study area. Since the term (rural-urban interaction) has not been examined in Jordan before, this is the first published study that concentrates on the development of rural areas within the scope of its relative urban area.

\section{Materials and methods}

Study area

The study was conducted for Bani Kinanah County, Irbid Governorate, located in the Northern part of Jordan (Fig. 1). The capital of Irbid Governorate is Irbid city which is the largest city in the governorate and the second urban area in the country with 929,224 inhabitants (DOS, 2019). The built-up area has an expansion rate of over $5 \%$ per year and its suburbs have become urbanized because of rural migration;
Fig. 1 Map of Irbid governorate and study area

$82.9 \%$ of the population is urban (Ababsa and Kholmayer, 2014, Gharaibeh et al., 2020).

According to population estimates (DOS, 2019), Bani Kinanah County has an estimated total population of 145,710. The county represents an important center for farming, where it produces about $11 \%$ of total olive production in Jordan. It occupies a unique site; bordered by the Syrian land from the north. Also, it is a touristic and historical region that goes back to 5000 BC (Irbid Governorate \& Ministry of Interior, 2016). Bani Kinanah County is one of the largest counties in Irbid governorate in terms of population (Fig. 1). It includes five municipal councils; AlKfarat, Al-Saru, Al-Shu'lah, Al-Yarmouk, and Khalid Bin Al-Walid. The county includes 27 towns with a town population ranging between 182 and 12,941 inhabitants (DOS, 2019).

Sama El-Roosan town is the rural administrative center of the county. This town holds many governmental buildings including the Directorate of Health, the Directorate of Education, the Social Security Corporation, the Department of Lands and Survey office, and the Directorate of Agriculture. It also includes a large hospital (AL Yarmouk Hospital), two civil service consumer corporations, and one school for vocational training.

\section{Data collection}

A household field survey was conducted for all towns in the study area where questionnaires were filled by the residents of each town. A total of 810 persons were contacted and interviewed. The survey included 27 towns, which represented all towns in the study area (county). About 30 questionnaires were conducted in each town. The questionnaires were distributed at the bus stops in the towns of residence, the rural center, and the urban center. The data collection was active at 7:00 am-9:00 am and after 2:00 pm to target more subjects on working days. The sampling was random among commuters. Other questionnaires targeted people at the clinics, high schools, shops, and vegetable markets in each town. This took place between 10:00 am and 1:00 pm on working days. All sampling took place in the month of October 2019. 


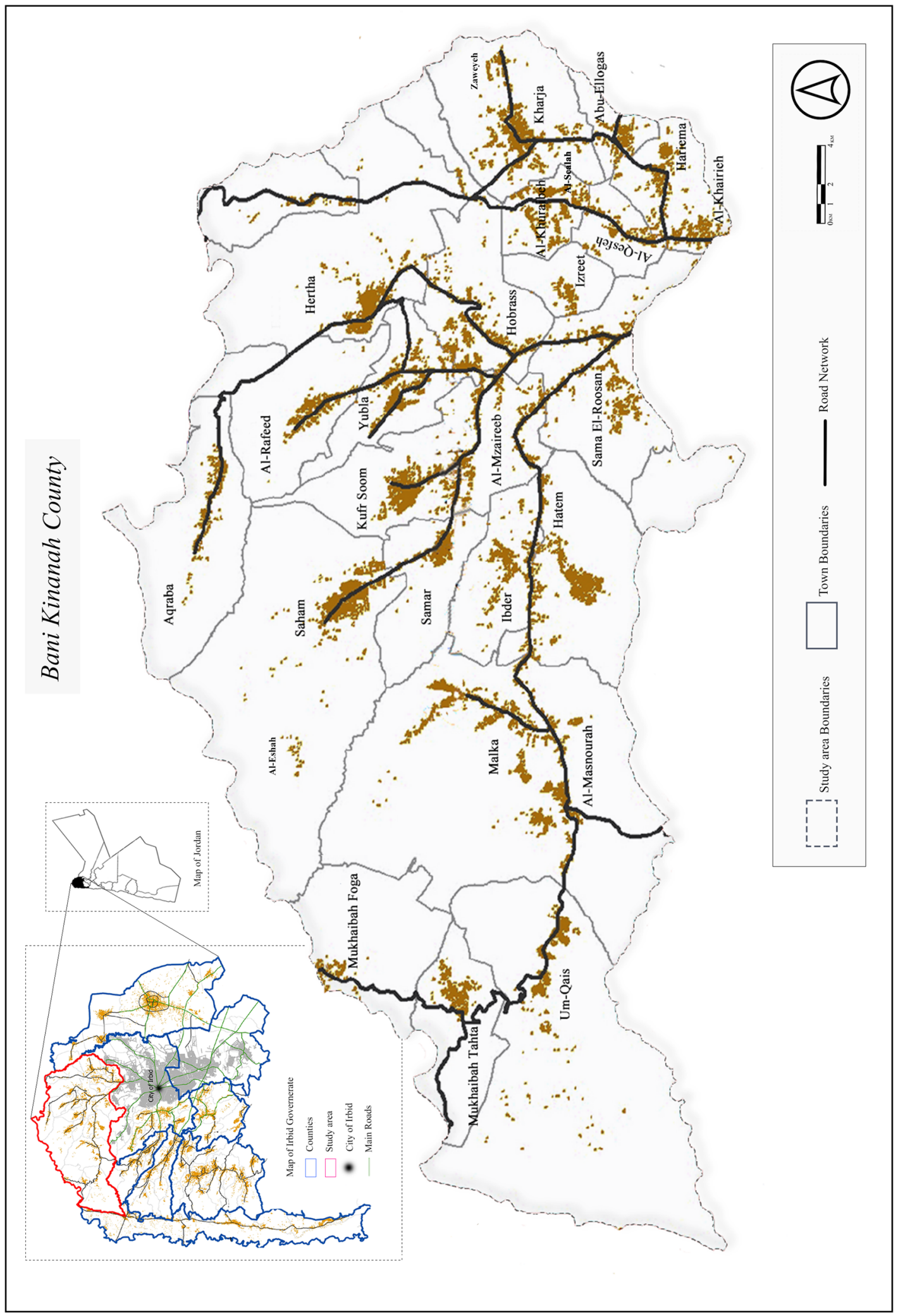


The questionnaire included demographic and socioeconomic questions, locational questions, and service attainment questions. It asked about most of the commonly used services that can be obtained at the urban center, the rural center, the town of residence, or other surrounding towns. The questionnaire targeted many of the daily, weekly, and monthly purchases by the rural population. In addition, the questionnaire was acquired about the place of work for each person. The questions aimed at exploring the types of rural-urban connections regarding shopping, education, healthcare, and recreation. It also explored the place of work as opposed to the place of commodity attainment.

The questionnaire is divided to seven sections that address (1) socio-economic characteristics of the residents (household size, household income, and employment status); (2) shopping services which include place types where they shop (shopping mall, large stores, small stores, food stores, non-food stores, and fruit and vegetable stores) in addition to products they shop for (everyday purchased products, seasonal products, and special items); (3) medical services (primary health centers, dental clinics, pharmacies, and hospitals) in terms of availability, frequency, and cause of utilization; (4) educational services (kindergarten, primary school, secondary school, vocational training, university) in terms of availability and the number of family members involved in each type of education; (5) recreational services (children play areas, public gardens, sports clubs, sporting events, and community hall events) in terms of availability, reason for attendance, and frequency of attendance; (6) national transportation services including frequency of utilization within and outside the county; (7) and place of employment (in or outside the county).

\section{Data Analysis}

To determine the locations and magnitude of utilization in each location, the study calculated the percentage of utilized service in each location selected by the respondents to measure the level of dependence as it was being met by the City of Irbid (referred to as urban center); by the county administrative center of Sama El-Roosan (referred to as rural center); and by the individual towns of the county. These three were compared throughout the body of this research. The examined utilization included shopping, education, and medical and recreational services.

County towns' interaction with their rural center and the urban center was analyzed by calculating the percentages of service utilization in the rural center and the urban center by each town in the county. Simple statistical tools were used also to realize the relation between the towns and both centers. Data collection also included personal observations of the targeted population of the study area.

The data was subject to quantitative analysis using SPSS software:

1 Means, which are used to measure the extent of service utilization in each location.

2 Standard deviation, which measures the significance of service utilization.

3 Regression model analysis was used to measure the impact of distance on service (shopping, educational, medical, and recreational) utilization by rural towns in the urban center, as well as the relationship between distance and these services utilization by rural towns in the Rural Center.

\section{Results}

Socioeconomic characteristics of the surveyed population

The socioeconomic characteristics of the surveyed population (age between 16 and 70 years with $30 \%$ female participation) are presented per household in Table 1 . The average household size of respondents is 5.9; the average household income is $432 \mathrm{JD} \backslash$ month; the unemployment percentage is $12.5 \%$. The majority of employed respondents are in the government and military sectors $(35.1 \%$ in the government sector and $16.9 \%$ in the military).

Where do residents of Bani Kinanah County obtain their needed services?

Results showed that the uses of shopping services were concentrated $(57.4 \%)$ in the urban center. and only $6.9 \%$ in the rural center (Sama El-Roosan) (Fig. 2). Also, $26.0 \%$ of educational services were met in the urban center, whereas only $14.7 \%$ were met in the rural center (Fig. 2). Other uses distributed in 
Table 1 Socioeconomic characteristics of the respondents in Bani Kinanah county

\begin{tabular}{|c|c|c|c|c|c|c|c|}
\hline \multicolumn{2}{|c|}{ Household size } & \multicolumn{2}{|c|}{ Avg. monthly income (JD) } & \multicolumn{2}{|c|}{ Household members attending university } & \multicolumn{2}{|l|}{ Employment } \\
\hline Categories & Number $(\%)$ & Categories & Number $(\%)$ & Categories & Number $(\%)$ & Sector & Number $(\%)$ \\
\hline $2-4$ & $92(11.3)$ & $0-200$ & $54(6.6)$ & 0 & $336(41.5)$ & Unemployment & $101(12.5)$ \\
\hline $4-6$ & $334(41.2)$ & $200-400$ & $442(52.0)$ & 1 & $203(25.1)$ & Gov. worker & $284(35.1)$ \\
\hline $6-8$ & $287(35.4)$ & $400-600$ & $236(29.1)$ & 2 & $158(19.5)$ & Military & $137(16.9)$ \\
\hline $8-10$ & $88(10.8)$ & $600-800$ & $58(7.1)$ & 3 & 94 (11.6) & Farming & $51(6.3)$ \\
\hline $10-12$ & $8(1)$ & $800-1000$ & $37(4.5)$ & 4 & $17(2.1)$ & Small business & $116(14.3)$ \\
\hline \multirow[t]{2}{*}{$12-14$} & $1(0.01)$ & $1000-1200$ & $3(0.03)$ & 5 & $2(0.2)$ & Craftsman & $69(8.5)$ \\
\hline & & & & & & Other & $52(6.4)$ \\
\hline \multicolumn{2}{|c|}{ Total: 810 (100) } & \multicolumn{2}{|c|}{ Total: $810(100)$} & \multicolumn{2}{|l|}{ Total: $810(100)$} & \multicolumn{2}{|l|}{ Total: 810 (100) } \\
\hline
\end{tabular}

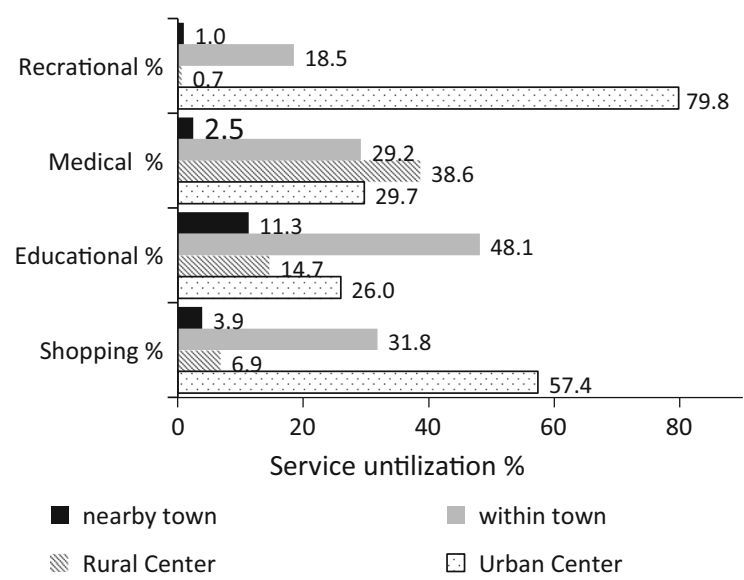

Fig. 2 Distribution of shopping, educational, medical, and recreational utilization \% in Urban, Rural, within the town, and nearby town within Bani Kinanah county

convergent percentages ranged between $0 \%$ and $4.3 \%$ among other locations. Results showed a significant concentration of recreational service utilization in the urban center $(79.8 \%$ ) (Fig. 3a). Other uses were distributed in approximate portions ranging between $0.0 \%$ and $2.4 \%$ among other locations (Fig. 2). Medical utilization was concentrated mainly in two locations; the urban center $(29.7 \%)$ and the rural center (38.6\%) (Fig. 2). The service utilization was divided between the urban center and county towns, where the highest utilization was in the urban center. The rural center showed higher utilization among other local towns in terms of shopping, education, and medical services. (Fig. 2).
County towns' interaction with their rural center and the urban center in terms of service utilization

Shopping utilization in the urban center ranged from 35 to $71 \%$ ( $\mathrm{SD}=8.7$ ) (Table 2). The majority of the towns shared convergent utilization percentages; where 25 towns of 27 shared percentages that ranged between 45 and $71 \%$ (Table 2). This means that they all shared high utilization percentages for shopping in the urban center. The lowest utilization values were found in both the rural center (35\%) and Hobrass town $(37 \%)$. This is probably due to the size of the facilities that are primarily larger in these two places than they are in other towns. In addition to the availability of a variety of stores that allow the shopping population to compare services and choose what suits them among the available ones. However, since the urban center provides more varieties, better services, and larger facilities, it remained as a stronger service provider for the rural population $(45-71 \%)$.

The details of this study show that shopping malls are available only in the urban center and the rural center and the dependence is $98.3 \%$ and $1.7 \%$ respectively. The dependence on large stores was $51.2 \%$ and $29.0 \%$ for the urban and rural centers respectively. However, when considering smalls stores that are readily available in most towns, the dependence was dispersed all over the towns ranging between $7.9 \%$ for the rural center down to $2.3 \%$ in the town of Al-Esheh. For food stores, the dependence on the urban center is $29.3 \%$ and the rural center is $20.0 \%$. However, for non-food stores, the county is highly dependent on the urban center (78.0\%). This is due to 

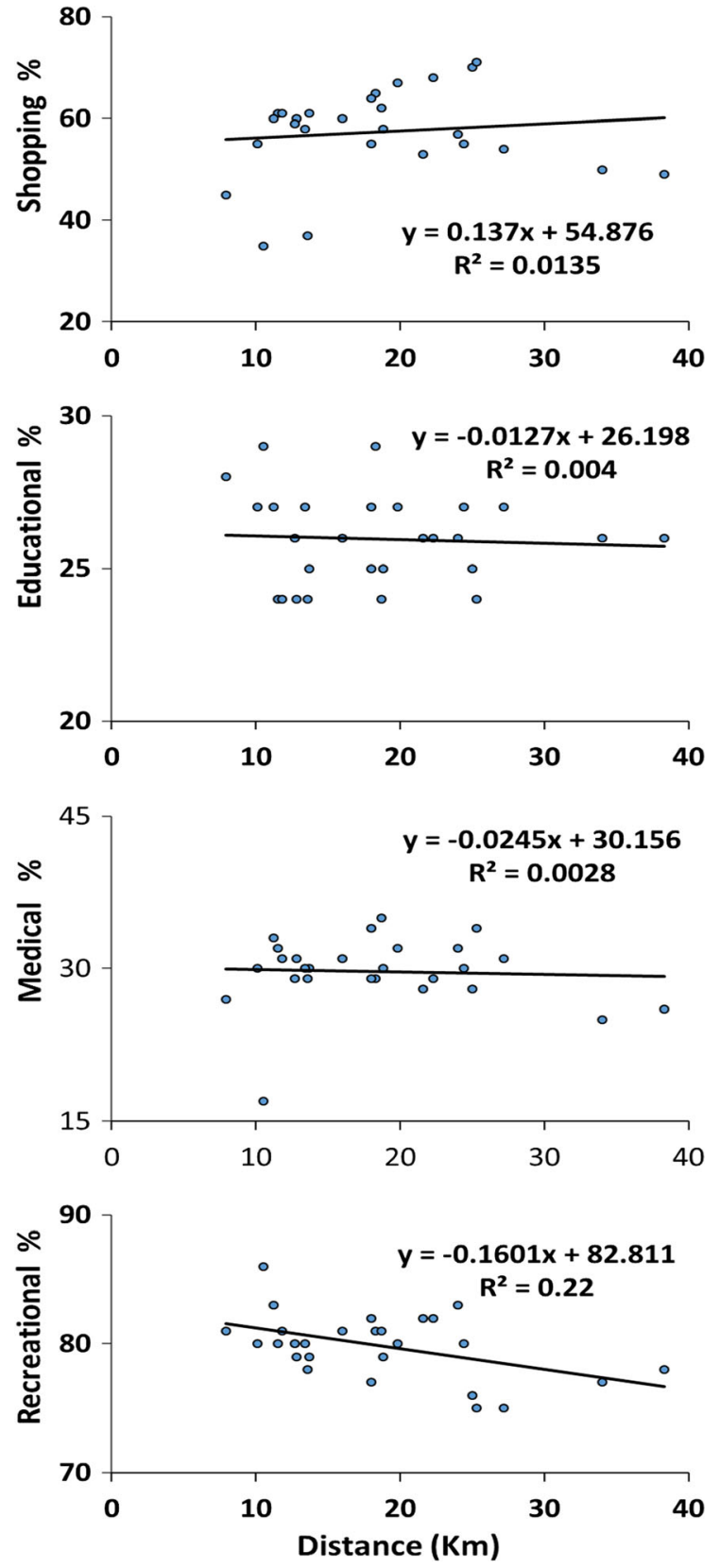

Fig. 3 Relationship between distance and services (shopping, educational, medical, and recreational) utilization by rural towns in Urban Center

the availability of a variety of store types in the urban center with larger sizes and more reliable kinds. Since the cafes and restaurants are mainly in the urban center the dependence is largely on it (87.4\%). Unfortunately, there are limited choices for this service in the county of Bani Kinanah despite the availability of many scenic places and archeological sites in the county. Although this county is home to many agricultural activities, the reliance on the urban center for agricultural product stores is about $56.9 \%$.

The respondents reveal that the main reasons that push the residents to use shopping services outside the county are as follows:
A Unavailability of shopping services in the county $(32.2 \%)$.
B Low quality of shopping services in the county (13.9).
C No variety of shopping services in the county (44.4\%).
D The use of shopping services outside the county because of the engagement in work or education there $(1.6 \%)$.
E The high price of shopping services in the county $(7.9 \%)$.

The frequency of uscing the urban center is overly stressed. $39.3 \%$ of the respondents use the urban center two to four times a month. $31.0 \%$ use the urban center five to seven times a month. The dependence is even greater for some, where $8.2 \%$ use it more than seventeen times a month.

The test of the relation between distance and shopping utilization in the urban center showed a slight increase in the utilization with the increase of distance from the urban center where $\left(\mathrm{R}^{2}=0.014\right)$ (Fig. 3). So, the shopping service utilization in the urban center was not affected significantly by distance. On the other hand, the variation of shopping utilization in the rural center was stronger and inversely related to distance (Fig. 4). Shopping utilization in the rural center ranged from $0.06 \%$ to $36 \%$ and with a high standard deviation (Table 3). A clear gap was found among towns in using shopping services in the rural center, where the majority of towns shared low utilization for shopping in the rural center and only three towns shared very high utilization percentages (Table 3). The increase in distance from the rural center was accompanied by a decrease in shopping utilization, where $\left(\mathrm{R}^{2}=0.37\right)$ (Fig. 4) indicating that utilization of services in the rural center is affected by distance rather than utilization shared in the urban center.

The utilized educational services in the urban center were $26 \%$ of total educational uses. The town's utilization of educational services in the urban center 
Table 2 Utilization (\%) of different services in the Urban Center for all towns of Bani Kinanah county

\begin{tabular}{|c|c|c|c|c|c|c|c|}
\hline Town & $\begin{array}{l}\text { Distancel } \\
\mathrm{km}\end{array}$ & Pop & $\begin{array}{l}\text { Shopping } \\
\text { utilization (\%) }\end{array}$ & $\begin{array}{l}\text { Educational } \\
\text { utilization }(\%)\end{array}$ & $\begin{array}{l}\text { Medical } \\
\text { utilization }(\%)\end{array}$ & $\begin{array}{l}\text { Recreational } \\
\text { utilization }(\%)\end{array}$ & $\begin{array}{l}\text { Job } \\
\text { utilization } \\
(\%)\end{array}$ \\
\hline Abu-Ellogas & 11.5 & 1792 & 61 & 24 & 32 & 80 & 27 \\
\hline Al-Eshah & 25.3 & 156 & 71 & 24 & 34 & 75 & 10 \\
\hline Al-Khairieh & 7.9 & 1350 & 45 & 28 & 27 & 81 & 22 \\
\hline Al-Khuraibeh & 12.8 & 2142 & 60 & 24 & 31 & 79 & 21 \\
\hline Al-Masnourah & 24.0 & 5502 & 57 & 26 & 32 & 83 & 28 \\
\hline Al-Mzaireeb & 13.4 & 2877 & 58 & 27 & 30 & 80 & 13 \\
\hline Al-Qesfeh & 11.2 & 1384 & 60 & 27 & 33 & 83 & 9 \\
\hline Al-Rafeed & 22.3 & 2971 & 68 & 26 & 29 & 82 & 16 \\
\hline Al-Sealah & 11.8 & 1384 & 61 & 24 & 31 & 81 & 18 \\
\hline Aqraba & 25.0 & 4063 & 70 & 25 & 28 & 76 & 13 \\
\hline Hariema & 10.1 & 6340 & 55 & 27 & 30 & 80 & 19 \\
\hline Hatem & 18.8 & 9427 & 58 & 25 & 30 & 79 & 30 \\
\hline Hertha & 18.3 & 6762 & 65 & 29 & 29 & 81 & 16 \\
\hline Hobrass & 13.6 & 5766 & 37 & 24 & 29 & 78 & 10 \\
\hline Ibder & 18.0 & 4247 & 55 & 25 & 29 & 82 & 19 \\
\hline Izreet & 12.7 & 1712 & 59 & 26 & 29 & 80 & 16 \\
\hline Kharja & 13.7 & 8866 & 61 & 25 & 30 & 79 & 18 \\
\hline Kufr Soom & 18.0 & 11,344 & 64 & 27 & 34 & 77 & 13 \\
\hline Malka & 24.4 & 11,706 & 55 & 27 & 30 & 80 & 24 \\
\hline Mukhaibah Foga & 38.3 & 2803 & 49 & 26 & 26 & 78 & 22 \\
\hline Mukhaibah Tahta & 34.0 & 3637 & 50 & 26 & 25 & 77 & 25 \\
\hline Saham & 21.6 & 9617 & 53 & 26 & 28 & 82 & 11 \\
\hline $\begin{array}{l}\text { Sama El-Roosan } \\
\text { (rural center) }\end{array}$ & 10.5 & 6340 & 35 & 29 & 17 & 86 & 50 \\
\hline Samar & 18.7 & 5589 & 62 & 24 & 35 & 81 & 34 \\
\hline Um-Qais & 27.2 & 6124 & 54 & 27 & 31 & 75 & 9 \\
\hline Yubla & 19.8 & 7432 & 67 & 27 & 32 & 80 & 16 \\
\hline Zaweyeh & 16.0 & 1824 & 60 & 26 & 31 & 81 & 6 \\
\hline St. Dev & & & 8.7 & 1.5 & 3.5 & 2.5 & 9.4 \\
\hline mean & & & 57.4 & 26.0 & 29.7 & 79.9 & 19.1 \\
\hline CV\% & & & 15.2 & 5.7 & 11.7 & 3.2 & 49.1 \\
\hline
\end{tabular}

ranged from 24 to $28 \%$ (Table 2). All towns within the county shared very convergent utilization percentages in the urban center. For the Rural Center, $14.7 \%$ of educational services were utilized there (Table 3). Service utilization ranged between $0.0 \%$ and $60 \%$ with a relatively high standard deviation of 16.3 (Table 3 ). Test of variation in utilization with the changes in distance from Rural Center showed that farther towns shared lower utilization, where $\left(R^{2}=0.20\right)$ (Fig. 4).
The majority of towns in the county shared low utilization ranging between $0.0 \%$ and $25 \%$. On the other hand, Ibder, Mzaireeb, and Izreet towns which were in approximate distance from the Rural Center shared the highest utilization percentages ranging between 52 and $60 \%$. However other towns with approximate distance shared minor utilization percentages such as Hariema, Al-Khairieh, and Al- 

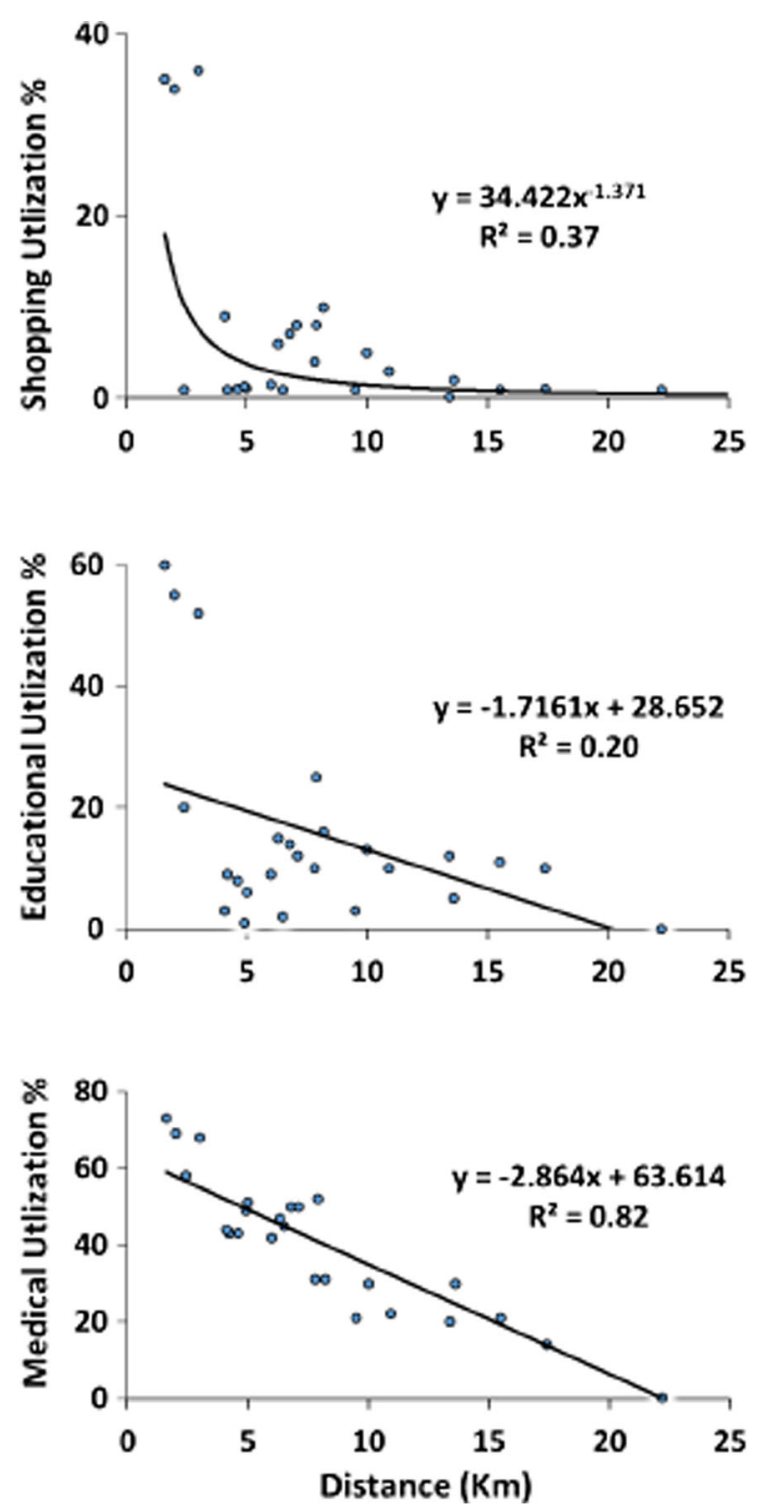

Fig. 4 Relationship between distance and services (shopping, educational, medical, and recreational) utilization by rural towns in Rural Center

Sealah. This indicated again that distance from the Rural Center is not the only factor affecting utilization.

In more detail, the utilization of kindergarten, primary school, and secondary school use are almost always within the town of residence or in a near town. The availability of the schools depended on both the town population and its proximity to the urban center. Vocational training is available in the rural center $(68.9 \%)$ in Hakama $(21.4 \%)$ and the urban center $(9.8 \%)$. All university students depended on Jordan's urban centers (cities) for their education due to the unavailability of any universities within the county of Bani Kinanah.

For medical services, $29.7 \%$ were utilized in the urban center, however, towns' utilization of medical services in the urban center ranged between 17 and $35 \%$ with a standard deviation of 3.5 (Table 2). The table shows that all towns except for the rural center shared very convergent percentages ranging between 25 and $35 \%$ with a standard deviation of 3.5. On the other hand, the study found a higher variation in the utilization of medical service utilization in the rural center among towns in the county which ranged between 1 and $69 \%$ with a standard deviation of 19.3 (Table 3).

In more detail, the Bani Kinanah depended on its urban center, its rural center, and on Hamiema for primary healthcare centers $(12.0 \%, 13.0 \%$, and $14.0 \%$ respectively). Dental care was mainly available in the urban center $(52.5 \%)$, however, the rural center $(13.1 \%)$ and half the towns also provided dental care. Pharmacies are available in 14 towns, however dependence on the urban center reached $40.0 \%$, on the rural center reached $22.0 \%$, and on Hebras reached $10.0 \%$. The dependence on hospitals was divided between the hospital at the rural center $(53.0 \%)$ and the many hospitals at the urban center $(47.0 \%)$. The respondents believe that the medical care quality is lower in the rural clinics and the hospital (42.4\%) therefore rely on the medical services in the urban center. Others believe that not all medical services are available in the local hospital (27.6\%) therefore choose to go to the urban center in addition to the variety of options when wanting to visit private doctors. Some indicated that the covering health insurance type is what controls their destination (10.0\%). Some places are not covered by health insurance companies.

Also, results indicated a significant impact of distance from the rural center on the utilization of medical services. The increase in distance was highly correlated with a decrease in utilization $\left(\mathrm{R}^{2}=0.82\right)$ (Fig. 4). Most of them occasionally choose to go to urban healthcare $(61.0 \%) .36 .9 \%$ of the respondents say that they always go to the urban center while very few indicated that they will never use the rural center for medical care.

Data showed that $79.8 \%$ of recreational services were utilized in the urban center. Utilization ranged 
Table 3 Service utilization (\%) in the Rural Center among all towns in Bani Kinanah county

\begin{tabular}{|c|c|c|c|c|c|c|}
\hline Town & $\begin{array}{l}\text { Distance } \\
\backslash \mathrm{Km}\end{array}$ & $\begin{array}{l}\text { AVG. income } \\
\text { JDD }\end{array}$ & $\begin{array}{l}\text { Shopping } \\
\text { utilization }(\%)\end{array}$ & $\begin{array}{l}\text { Educational } \\
\text { utilization }(\%)\end{array}$ & $\begin{array}{l}\text { Medical } \\
\text { utilization (\%) }\end{array}$ & $\begin{array}{l}\text { Recreational } \\
\text { utilization }(\%)\end{array}$ \\
\hline Abu-Ellogas & 6.5 & 388 & 0.9 & 2 & 45 & - \\
\hline Al-Eshah & 13.4 & 378 & 0.1 & 12 & 20 & - \\
\hline Al-Khairieah & 4.2 & 500 & 0.9 & 9 & 43 & - \\
\hline $\begin{array}{l}\text { Al- } \\
\text { Khuraibeh }\end{array}$ & 4.6 & 390 & 1 & 8 & 43 & - \\
\hline $\begin{array}{l}\text { Al- } \\
\text { Masnourah }\end{array}$ & 7.9 & 425 & 8 & 25 & 52 & - \\
\hline Al-Qesfeh & 4.1 & 460 & 9 & 3 & 44 & - \\
\hline Al-Rafeed & 10.0 & 390 & 5 & 13 & 30 & - \\
\hline Al-Sealah & 5.0 & 450 & 1.1 & 6 & 51 & - \\
\hline Aqraba & 15.5 & 473 & 0.9 & 11 & 21 & - \\
\hline Hariema & 4.9 & 373 & 1.3 & 1 & 49 & - \\
\hline Hatem & 8.2 & 400 & 10 & 16 & 31 & - \\
\hline Hertha & 7.8 & 430 & 4 & 10 & 31 & - \\
\hline Hobrass & 2.4 & 431 & 0.9 & 20 & 58 & - \\
\hline Ibder & 3.0 & 420 & 36 & 52 & 68 & - \\
\hline Izreet & 1.6 & 420 & 35 & 60 & 73 & - \\
\hline Kharja & 6.0 & 490 & 1.5 & 9 & 42 & - \\
\hline Kufr Soom & 6.8 & 491 & 7 & 14 & 50 & - \\
\hline Malka & 13.6 & 520 & 2 & 5 & 30 & - \\
\hline $\begin{array}{l}\text { Mukhaibah } \\
\text { Foga }\end{array}$ & 26 & 390 & 0.06 & 0 & 0 & - \\
\hline $\begin{array}{l}\text { Mukhaibah } \\
\text { Tahta }\end{array}$ & 22.2 & 300 & 0.9 & 0 & 0.1 & - \\
\hline Mzaireeb & 2 & 410 & 34 & 55 & 69 & - \\
\hline Saham & 10.9 & 570 & 3 & 10 & 22 & - \\
\hline Samar & 6.3 & 366 & 6 & 15 & 47 & - \\
\hline Um-Qais & 17.4 & 420 & 1 & 10 & 14 & - \\
\hline Yubla & 7.1 & 450 & 8 & 12 & 50 & - \\
\hline Zaweyeh & 9.5 & 490 & 0.9 & 3 & 21 & - \\
\hline St. Dev & & 57.3 & 10.8 & 16.3 & 19.3 & \\
\hline mean & & 431.7 & 6.9 & 14.7 & 38.6 & \\
\hline CV\% & & 13.3 & 157.2 & 111.2 & 50.0 & \\
\hline
\end{tabular}

between 75 and $86 \%$ (Table 2). On the other hand, data showed that towns' utilization of recreational services in the rural center is $0.01 \%$ (Table 3). Only the residents of the rural center used recreational services within the rural center, which represent $0.7 \%$ of total utilization. Children's play areas are mostly approached in the urban center $(60.0 \%)$. Public gardens in the urban center are utilized by $66.3 \%$ of the respondents. Community halls are approached for their availability in urban areas only (100\%). Sports clubs are now more available at the town level, however, still, $71.5 \%$ depend on the urban center for this service. All sports events and matches take place in the urban center (100\%). The respondents addressed the unavailability of recreational services in their county $(63.4 \%)$. Some also addressed the lowered quality of entertainment (27.6\%) and the lack of variety of recreational services $(9.0 \%)$. Respondents 
leave Bani- Kinanah County always when they need to use recreational services $(51.3 \%)$. $37.6 \%$ of them leave the county occasionally and $11.1 \%$ never leave the county.

The overall interaction within the County

The analysis of the spatial distribution of service utilization within the county shows that percentages of services utilized in near towns in the county are lower than services utilized in the town of residence among shopping, recreational and educational services. For shopping services, $30.6 \%$ of services are utilized in the town of residence and $11 \%$ in near towns within the county. For recreational services, $14.2 \%$ of services are utilized in the town of residence and $6.2 \%$ in near towns in the county. For educational services, $50.9 \%$ of services in the town of residence and $19 \%$ in near towns within the county. For medical services, $29 \%$ of services are utilized in the town of residence and 33\% in near towns within the county. This indicates that residents of Bani Kinanah County are not integrated efficiently with their surrounding towns especially when the majority of their services are utilized in the Urban Center (Fig. 2).

\section{Job service utilization}

The analysis of the spatial distribution of job utilization shows that $43 \%$ of respondents work in Bani Kinanah County. However, only $20 \%$ of them work in the Urban Center; about $10 \%$ are employed at a nearby county; while $14.5 \%$ rely on other governorates for their employment; finally, the remaining $12.5 \%$ are unemployed (Fig. 2). These results showed that utilization of job services in the Urban Center was the lowest compared with other services (shopping, education, medical and recreational services). The average use of different services in the Urban Center exceeds $50 \%$ of total uses. On the other hand, only $20 \%$ of job services are utilized there. Job dependence on the Urban Center ranged between 6 and 50\% among all towns with a standard deviation of 9.4 (Table 2). Also, Job utilization variations were the highest among other utilization services (Table 2).

\section{Discussion}

Utilization results showed significant concentration in the urban center especially for shopping and recreational use where more than half of shopping services and more than three-quarters of recreational services are met there. Service utilization in the rural center seems to be minor compared to the urban center, especially in shopping and recreational services; overall, only $6.8 \%$ of shopping utilization and $0.7 \%$ of recreational services were met in the county rural center (Fig. 2). For educational and medical services, it appears to be less met in the urban center. About one-quarter of the educational services and more than one-third of medical services were met in the county and the rural center. the is probably due to the availability of a hospital in the county and the meeting of all high school and lower school grades within the county. However, when they join university education, their destination must be outside the county (Fig. 5).

The examination of the actual use of services showed a strong interaction between county towns and the urban center of Irbid city. The utilization of services in the urban center was high and stable among all towns in the county where towns showed high utilization with low variation in service utilization in the urban center. However, the utilization of services in the rural center of the county was lower and unstable. Towns in the county showed significant variation among them in their service utilization in the rural center.

The results showed high service utilization in the urban center with minor variations among towns faced by lower utilization in the rural center with higher variation among towns. To realize this instability of service utilization in the rural center, the study

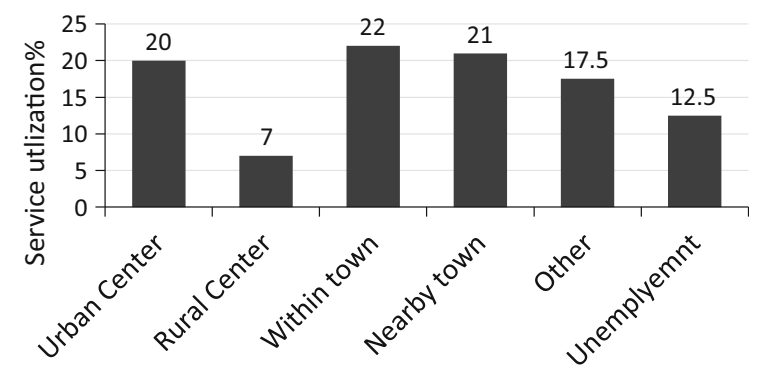

Fig. 5 Job service utilization in the urban center, in the rural center, within the town of residence, and in a nearby town 
examined the relationship between distance from the rural center and service utilization (Fig. 3 and 4). The analysis showed that increasing distance from the rural center decreased the utilization. Because of their proximity to the rural center, certain towns were able to take advantage of its services. At the same time, some neighboring towns located close to the rural center had relatively low rates of utilization, indicating a substantial disparity in service usage in the rural center. This is most likely owing to the simultaneous proximity of these towns, in particular, to the urban center and the rural center. As a result, people of these towns will favor the urban center due to the abundance of amenities there similar to the previous study carried out by (Heffner \& Twardzik, 2015). Learning from Faggio et al., (2014), Li et al., (2019), and Rudiarto et al., (2020), it is probably a good practice to create policies that should encourage the self-dependence of the rural population leading to more resilient communities that sustain their land and rural practices. As indicated by the World Bank report in 2018, it is also important to preserve farming practices in particular to stop the dropping of the number of people working in farming. Moreover, the study analyzed the role of household income in service utilization in the rural center. The analyses also failed to explain this gap in service utilization where the correlation between average household incomes in each town with the utilization of services in the rural center was weak. The analysis showed that increasing household income wasn't a factor that increased the utilization of services in the rural center among all towns. Furthermore, data in Table (3) displayed that the average income for these towns with high service utilization in the rural center such as Izreet, Mzaireeb, and Ibder town are close to those with low service utilization which doesn't explain the significant variation in the use of services.

It was noted that the local public transport system within the county plays a significant role in reducing the utilization of services in the rural center. The route of the local transportation system of the study area is from the town directly to the urban center with no movement within local towns. In this way, the local transit bus movement reduces the interaction between towns where a large part of county towns cannot access the rural center by bus. The Al-Sealah, Qesfah, Hariema, Zaweyeh, Al-Khuraibeh, Al-Khairieh, AbuEllougas, and Kharja towns don't have public transportation access to the rural center. Rather, it provided commutes from their towns directly to the urban center. However, data from the survey showed that these towns' dependence on the public transport system in their commutes within the county was minor compared to other local towns. In addition, the weakness of spatial connection by road network negatively impacted the interaction with the rural center. Despite the closeness of some towns (such as Al-Khairieh, Hariema, Qesfah, and Al-Sealah towns) to the rural center, the absence of direct connection by road network made it harder for them to access the rural center.

The analysis results for the distance from the rural center and the economic status of the residents were barriers for rural service utilization. The town-to-town street network could also be the cause of the weakness of ties. The tree-like street network did not permit the linkage of street ends as it was also impacted by the rugged topography of the county and its place by the borders (Fig. 1). This result was also shared by Zobena et al. (2012) who found that both transit and low income could discourage local service catering at the county. However, they supported that it was easier and more beneficial to support public transportation to obtain services at the urban center. In our research, we valued time and supported the provision of, at least, recreational and shopping services at the rural center. Lagakos (2020) and Rudiarto et al. (2020) also supported strengthening rural ties to close the gap of depending on the urban center. The fast-growing population with the presence of more refugees in this area could cause extra stress on service provision.

The emphasis on strengthening the spatial connections with urban centers while ignoring the interaction within rural regions could lead to an increased burden on the urban center and reduced pressure on the role of small towns in rural developments. Some examples from the literature were successful in reducing pressure on the urban center by provisioning services in the rural center (Rezvani et al., 2009; Sharifinia, 2013). There are many recent examples where small-town initiatives went bankrupt in the late 1990s due to nonagricultural activities taking place in cities and towns (Li et al., 2019).

The analysis of job utilization showed minor dependence on the urban center of Irbid city. It was minor compared to the dependence on other services. $20 \%$ of total job opportunities were met in the urban 
center of Irbid while more than half of the total services were utilized there. The daily service dependence played a major role in the integration with the urban center. The high availability of job opportunities in the county ( $43 \%$ of job opportunities were met within the county) did not generate a strong economic growth that could attract the needed services because the majority of these jobs were in the public sector and small businesses. To some, this is called the ruralurban skills gap such as that presented in the research on Canadian rural towns (Zarifa et al., 2019). In their case, skill and literacy were not comparable to the urban residents and have played a role in increasing the gap size in this regard. They were less motivated to indulge in ways of education and future employments that were not available in their rural locations. They had stronger ties with their regions. Our research does not show this type of attitude among rural residents. They were willing to commute to the urban center for education and also were prone to migrate to the urban center if they secured a job. Besides, the income assisted the county residents financially and created an ability to buy a private car, however, it didn't help to attract businesses to the county. Rural job dependence on the urban center was considered as the main efficient strategy for rural economic growth (Castle et al, 2011; Lavesson, 2017; Partridge et al, 2008). Therefore, the study concluded that the urban center is exhausting rural resources rather than creating economic growth. The county residents secured most of their jobs in the county but not all their services. Unlike the case of Zobena et al., (2012) while similar to the study of Li et al., (2019), it appeared that provisioning jobs in the rural region will grant the residents a more sustainable and resilient existence. However, there are no guarantees that they can sustain their existence without the support of Urban jobs. The improvements in within-county commutes will be very helpful in creating a more interdependent relationship between the county towns. This will probably improve service provision and jobs within the county towns as well.

\section{Conclusion}

The study concluded that the spatial movement of public transportation services and the weak poor road network between the rural center and other towns in the county were the major factors in reducing the interaction between the rural towns and the rural center. The route of public transport services is connected spatially with the urban center of Irbid city with no strong connections among local towns, which encouraged the movement to the urban center rather than to the rural center. An efficient road network is therefore crucial to the overall development of the rural municipal district. The current planning practices emphasized strengthening the spatial connections with the urban center while ignoring the potential role of the rural center in reducing the pressure on the urban center.

Furthermore, the location of the rural center which is the administrative center of the county indicates the absence of the future vision of its role as a center for supplied services and amenities. The provision of service in the rural center was not efficient due to its location. More centralized towns such as Hobrass may attract the residents to use services despite the absence of complete service coverage.

Strengthening the spatial connections with the urban center combined with weak connections between rural towns avoids the efficient utilization of the available services in rural areas. Thus, the availability of services in a specific location doesn't always mean efficient utilization. For example, recent research on COVID-19 healthcare stresses the importance of the centrality of the rural center location to support health services in counties (Lakhani, 2021).

Rural development strategies should take into account increasing the ties with large urban centers in the form of job commuting which is considered as the main development strategy for rural economies that do not pertain to their jobs within their regions. In other words, the effective development strategy for our case study should assist rural residents to generate income by increasing urban job services besides rural job services. It should also decrease the exhausting movement to the urban center and support within county transit to access other services by increasing the ties between rural towns.

\section{References}

Ababsah, M., \& Kholmayer, C. 2013. Atlas of Jordan: History, territories and society (pp. 715). France: Beyrouth. 
Adams, R.H.J., 2001. Nonfarm income, inequality, and poverty in rural Egypt and Jordan. The World Bank.

Alinaghipour, M., Pourramzan, I., \& Molaey Hashjin, N. (2021). Explanation of environmental livability of rural settlements around Rasht metropolis. Human Geography Research, 53(1), 1-22.

Anlimachie, M. A., \& Avoada, C. (2020). Socio-economic impact of closing the rural-urban gap in pre-tertiary education in Ghana: Context and strategies. International Journal of Educational Development, 77, 102236. https:// doi.org/10.1016/j.ijedudev.2020.102236

Department of Statistics (DOS), 2019. Estimated Population of the Kingdom by Municipality and Sex, at End-year 2019. Family and Population Surveys Directorate, Department of Population and Social Statistics. http://dosweb.dos.gov.jo/ DataBank/Population_Estimares/Municipalities2019.pdf

Awasthi, S. (2021). 'Hyper'-Urbanisation and migration: A security threat. Cities, 108, 102965.

Bryzhko, V. G., \& Bryzhko, I. V., (2019). Comprehensive assessment of the impact of road infrastructure development in a rural municipal area (Russia). Revista ESPaCiOS, 40(37).

Castle, E., Wu, J., \& Weber, B. (2011). Place orientation and Rural-Urban interdependence. Applied Economic Perspectives and Policy, 33(2), 179-204.

Cattaneo, A., Nelson, A., \& McMenomy, T. (2021). Global mapping of urban-rural catchment areas reveals unequal access to services. Proceedings of the National Academy of Sciences, 118(2).

Faggio, G., \& Silva, O. (2014). Self-employment and entrepreneurship in urban and rural labour markets. Journal of Urban Economics, 84, 67-85.

Garnelo, L., Parente, R. C. P., Puchiarelli, M. L. R., Correia, P. C., Torres, M. V., \& Herkrath, F. J. (2020). Barriers to access and organization of primary health care services for rural riverside populations in the Amazon. International Journal for Equity in Health, 19(1), 1-14.

Gashu, K. 2014. The role of small towns for surrounding rural development: The case of Metema Town, North West Ethiopia. Open Access Library Journal, 1, e930. https:// doi.org/10.4236/oalib.1100930

Gharaibeh, A. A., Jaradat, R. A., Okour, Y. F., \& Al-Rawabdeh, A. M. (2017). Landscape perception and landscape change for the city of irbid. Jordan. Journal Architecture \& Planning, 29(1), 89-104.

Gharaibeh, A., Shaamala, A., Obeidat, R., \& Al-Kofahi, S. (2020). Improving land-use change modeling by integrating ANN with cellular automata-markov chain model. Heliyon, 6(9), e05092. https://doi.org/10.1016/j.heliyon. 2020.e05092

Gharaibeh, A. A., Ali, M. H., Abo-Hammour, Z. S., Al Saaideh, M., 2021. Improving Genetic Algorithms for Optimal Land-Use Allocation. Journal of Urban Planning and Development, 147(4), 04021049. American Society of Civil Engineers. Doi: https://doi.org/10.1061/(ASCE)UP. 1943-5444.0000744.

Giuliani, M. V. (2003). Theory of Attachment and Place Attachment. In M. Bonnes, T. Lee, \& M. Bonaiuto (Eds.), Psychological theories for environmental issues (pp. 137-170). Ashgate.
Global Monitoring Report. (2013). Rural-Urban Dynamics and the Millennium Development Goals. World Bank and International Monetary Fund.

Heffner, K., \& Twardzik, M. (2015). The impact of shopping centers in rural areas and small towns in the outer metropolitan zone (the example of the Silesian Voivodeship). European Countryside, 7(2), 87.

Irbid Governorate - Ministry of Interior, 2016. Moi.gov.jo. N.p., Web. 6 Oct. 2016.

Karg, H., Bellwood-Howard, I., Akoto-Danso, E. K., Schlesinger, J., Chagomoka, T., \& Drescher, A. (2019). Smalltown agricultural markets in northern ghana and their connection to rural and urban transformation. The European Journal of Development Research, 31(1), 95-117. https://doi.org/10.1057/s41287-018-0171-2

Kassahun, G. (2014). The role of small towns for surrounding rural development: The case of metema town, North West Ethiopia. Open Access Library Journal, 1(6), 1-13. https:// doi.org/10.4236/oalib.1100930

Kihonge, E., 2014. The Role of Small and Medium Enterprises (SMEs) in small towns in Rural-Urban continuum: The case of Sagana and Carantina in Mt. Kenya Region, Central Kenya (Ph.D.). Université Blaise-Pascal.

Lagakos, D. (2020). Urban-rural gaps in the developing world: Does internal migration offer opportunities? Journal of Economic Perspectives, 34(3), 174-192. https://doi.org/10. 1257/jep.34.3.174

Lakhani, A. (2021). Introducing the percent, number, availability, and capacity [PNAC] spatial approach to identify priority rural areas requiring targeted health support in light of COVID-19: A commentary and application. The Journal of Rural Health, 37(1), 149-152. https://doi.org/10.1111/ jrh. 12436

Langemeyer, J., Madrid-Lopez, C., Beltran, A. M., \& Mendez, G. V. (2021). Urban agriculture-A necessary pathway towards urban resilience and global sustainability? Landscape and Urban Planning, 210, 104055.

Lavesson, N. (2017). When and how does commuting to cities influence rural employment growth? Journal of Regional Science, 57(4), 631-654.

Li, Y., Westlund, H., \& Liu, Y. (2019). Why some rural areas decline while some others not: An overview of rural evolution in the world. Journal of Rural Studies, 68, 135-143. https://doi.org/10.1016/j.jrurstud.2019.03.003

Markova, M. (2019). Rural-urban interaction inclusion in ongoing Latvia regional reform. Scientific Journal of Latvia University of Life Sciences and Technologies, Landscape Architecture, and Art, 15(15), 83-89. https://doi.org/ 10.22616/j.landarchart.2019.15.09

Mayer, H., Habersetzer, A., \& Meili, R. (2016). Rural-urban linkages and sustainable regional development: The role of entrepreneurs in linking peripheries and centers. Sustainability, 8(8), 745. https://doi.org/10.3390/su8080745

Meit, M., \& Knudson, A. (2020). Leveraging rural strengths to overcome population health challenges. American Journal of Public Health, 110(9), 1281-1282.

Moss, J. E., Jack, C. G., \& Wallace, M. T. (2004). Employment location and associated commuting patterns for individuals in disadvantaged rural areas in Northern Ireland. Regional Studies, 38(2), 121-136. 
OECD. 2013. Rural-Urban Partnerships: An Integrated Approach to Economic Development. OECD Rural Policy Reviews. Paris: OECD Publishing.

Partridge, M., Rickman, D., Ali, K., \& Olfert, M. (2008). Lost in space: Population growth in the American hinterlands and small cities. Journal of Economic Geography, 8(6), 5-22. https://doi.org/10.1093/jeg/Ibn038

Partridge, M. D., Ali, K., \& Olfert, M. R. (2010). Rural-to-urban commuting: Three degrees of integration. Growth and Change, 41(2), 303-335.

Polèse, M., \& Shearmur, R. (2006). Why some regions will decline: A Canadian case study with thoughts on local development strategies. Papers in Regional Science, 85(1), 23-46.

Rezvani, M., Shakoor, A., Ronizi, S. R. A., \& Roshan, G. (2009). The role and function of small towns in rural development using network analysis method case: Roniz rural district. Journal of Geography and Regional Planning, 2(9), 214-223.

Rudiarto, I., Hidayani, R., \& Fisher, M. (2020). The bilocal migrant: Economic drivers of mobility across the ruralurban interface in Central Java, Indonesia. Journal of Rural Studies, 74, 96-110. https://doi.org/10.1016/j.jrurstud. 2019.12.009

World Bank, 2018. Rural population estimates (\% of total population) - Jordan. The website is visited on June $1^{\text {st }}$ 2021. https://data.worldbank.org/indicator/SP.RUR. TOTL.ZS?locations $=\mathrm{JO}$

Salvati, L. (2020). Residential mobility and the local context: Comparing long-term and short-term spatial trends of population movements in Greece. Socio-Economic Planning Sciences. https://doi.org/10.1016/j.seps.2020.100910

Schaeffer, P., Loveridge, S., \& Weiler, S. (2014). Urban and rural: Opposites no more. Economic Development Quarterly, 28(1), 3-4. https://doi.org/10.1177/ 0891242413520089

Schönfelder, S., \& Axhausen, K. W. (2003). Activity spaces: Measures of social exclusion? Transport Policy., 10, 273-286. https://doi.org/10.1016/j.tranpol.2003.07.002

Sharifinia, Z. (2013). The role of small urban in rural development: A Case Study in Iran. Middle-East Journal of Scientific Research, 13(3), 432-439. https://doi.org/10.5829/ idosi.mejsr.2013.13.3.1929

Tacoli, C., (2004). The Role of Small and Intermediate Urban Centres and Market Towns and the Value of Regional
Approaches to Rural Poverty Reduction Policy (pp. 2-5). Helsinki: OECD DAC POVNET.

United Nations. (2011). Population Distribution, Urbanization, Internal Migration and Development: An International Perspective.

United Nations. 2018. Revision of World Urbanization Prospects. www.un.org/development/desa/publications/2018revision-of-world-urbanization-prospects.html

Vaughan, L., 2015. Suburban urbanities (p. 374). UCL Press.

Wales assembly governorate, Cardiff university and the university of wales, 2007. Small and market towns in rural Wales and their hinterlands (pp. 96-72). Wales: Wales Rural Observatory.

Wang, Z., Li, D., Cheng, H., \& Luo, T. (2020). Multifaceted influences of urbanization on sense of place in the ruralurban fringes of China: Growing, dissolving, and transitioning. Journal of Urban Planning and Development, 146(1), 04019026.

Woods, M., "Rural-Urban Linkages,” Kapfudzaruwa, F., Kudo, S., Matsuyama, K. and Allasiw, D.I. eds., 2020. RuralUrban Linkages and Sustainable Development: Case Studies from Africa (Vol. 6). Spears Media Press.

Zarifa, D., Seward, B., \& Milian, R. P. (2019). Location, location, location: Examining the rural-urban skills gap in Canada. Journal of Rural Studies, 72, 252-263. https://doi. org/10.1016/j.jrurstud.2019.10.032

Zhao, P., \& Yu, Z. (2020). Investigating mobility in rural areas of China: Features, equity, and factors. Transport Policy, 94, 66-77.

Zhou, W., Guo, S., Deng, X., \& Xu, D. (2021). Livelihood resilience and strategies of rural residents of earthquakethreatened areas in Sichuan Province China. Natural Hazards, 106(1), 255-275.

Zobena, A., Lace, I., \& Benga, E. (2012). Service provision and social cohesion in rural areas: Interaction between commuting, mobility and the residential preferences in Latvia, No 126119, 126th Seminar, June 27-29, 2012 Capri, Italy. European Association of Agricultural Economists. https:// doi.org/10.22004/ag.econ.126119

Publisher's Note Springer Nature remains neutral with regard to jurisdictional claims in published maps and institutional affiliations. 